\title{
MicroRNA let-7: A promising non-invasive biomarker for diagnosing and treating external genital endometriosis
}

\section{Diş genital endometriozis teşhisi ve tedavisi için umut verici non-invaziv biyobelirteç olarak MikroRNA let-7}

\author{
(1) Darya A. Pokrovenko', (1) Volodymyr Vozniuk², (1) Mykhailo V. Medvediev ${ }^{3}$ \\ ${ }^{1}$ Klinica Doctora Medvedeva, Dnipro, Ukraine \\ 2Lviv Regional Public Health Center, Lviv, Ukraine \\ 3 Dnipro State Medical University, Department of Obstetrics and Gynecology, Dnipro, Ukraine
}

\begin{abstract}
Objective: To evaluate the possibility of using microrna let-7 and mir-9 as non-invasive biomarkers for the diagnosis and treatment of external genital endometriosis.

Materials and Methods: We explored the samples of relatively healthy individuals and patients with endometriosis. All patients had undergone laparoscopic surgical treatment after clinical and laboratory examinations. We used RNA-GO to obtain total RNA from endometriosis samples excised by laparoscopic method. Next step involved reverse transcription for microRNA let-7 and mir-9. Correlation-regression analysis was performed using Mann-WhitneyWilcoxon method. Subsequently, receiver operating characteristic analysis was conducted to determine the possibility of using let-7 microRNA for noninvasive detection of endometriosis. The results of the analysis in all groups were tested considering the normality of statistical distribution.

Results: Mann-Whitney analysis showed that the difference in mir-9 mRNA between the groups with and without endometriosis, as well as between the groups with more clinically and histologically severe and mild endometriosis, was statistically insignificant. In addition, a significant difference was noted regarding let-7 microRNA between the groups with and without endometriosis, as well as between the groups with more clinically and histologically severe and mild endometriosis. Comparison with cancer antigen-125 (CA-125) showed that let-7 microRNA was a more specific test than CA-125.

Conclusion: MicroRNA let-7 had the best parameters (sensitivity, specificity, and predictive value of positive and negative results) among the biomarkers studied. These biomarkers may be used for early and sometimes preclinical diagnosis of endometriosis.
\end{abstract}

Keywords: Genital endometriosis, microrna let-7, microrna mir-9, cancer antigen-125

Öz

Amaç: Dış genital endometriozis tanı ve tedavisi için mikro-RNA let-7 ve mir-9'un invaziv olmayan biyobelirteçler olarak kullanım olasılığını değerlendirmek. Gereç ve Yöntemler: Nispeten sağlıklı bireylerin ve endometriozisli hastaların örneklerini araştırdık. Tüm hastalara klinik ve laboratuvar muayeneleri sonrasında laparoskopik cerrahi tedavi uygulandı. Laparoskopik yöntemle eksize edilen endometriozis hücre örneklerinden toplam RNA elde etmek için RNA-GO kullandık. Sonraki adım, mikroRNA let-7 ve mir-9 için ters transkripsiyon gerçekleştirmekti. Korelasyon-regresyon analizini yaptık ve MannWhitney-Wilcoxon yöntemini kullandık. Daha sonra, endometriozisin non-invaziv tespitinde let-7 mikroRNA kullanma olasılığını belirlemek için alıcı işlem karakteristikleri analizini gerçekleştirdik. Tüm gruplardaki analiz sonuçları, istatistiksel dağılımın normalliğinin değerlendirilmesi açısından test edildi.

Bulgular: Mann-Whitney analizi, endometriozisi olan ve olmayan hasta grupları arasında ve ayrıca klinik ve histolojik olarak daha şiddetli ve hafif endometriozisi olan gruplar arasında mir-9 mRNA açısından istatistiksel olarak anlamlı fark bulamadık. Aynı zamanda, endometriozisi olan ve olmayan hasta grupları arasında ve ayrıca klinik ve histolojik olarak daha şiddetli ve hafif endometriozisi olan gruplar arasında let-7 mikroRNA açısından anlamlı fark bulduk. Ca-125 ile karşılaştırma, let-7 mikroRNA'nın CA-125’e göre daha spesifik bir test olduğunu göstermiştir.

Sonuç: MikroRNA let-7, incelenen biyobelirteçler arasında en iyi parametrelere (duyarlılık, özgüllük, pozitif ve negatif prediktif değerler) sahiptir. Bu biyobelirteçler, endometriozisin erken ve bazen klinik öncesi teşhisi için kullanılabilir.

Anahtar Kelimeler: Genital endometriozis, mikro-RNA let-7, mikro-RNA mir-9, kanser antijeni-125

PRECIS: MicroRNA let-7 has the best parameters (sensitivity, specificity, and predictive value of positive and negative results) among the biomarkers studied, which may be used for early and sometimes preclinical diagnosis of endometriosis.

Address for Correspondence/Yazıșma Adresi: Prof. Mykhailo V. Medvediev, Dnipro State Medical University, Department of Obstetrics and Gynecology, Dnipro, Ukraine

Phone: +380677378117 E-mail:medvedev.mv@gmail.com ORCID ID: orcid.org/0000-0002-0443-0572

Received/Geliș Tarihi: 21.06.2021 Accepted/Kabul Tarihi: 29.08.2021

${ }^{\circledR}$ Copyright 2021 by Turkish Society of Obstetrics and Gynecology

Turkish Journal of Obstetrics and Gynecology published by Galenos Publishing House 


\section{Introduction}

Endometriosis has many symptoms that negatively affect the reproductive capability and quality of life of a woman ${ }^{(1)}$. This condition is characterized by the proliferation of endometrial tissue outside of the uterine cavity, which causes pelvic pain and infertility ${ }^{(2)}$. The prevalence of endometriosis varies between $5 \%$ and $10 \%$ in all women, $20 \%-25 \%$ in patients with gynecologic conditions, and 45\%-50\% among women with infertility. The true incidence of endometriosis is not exactly known $^{(3)}$. Endometriosis is a common condition and occurs irrespective of ethnicity, race, socioeconomic conditions, and age $^{(4)}$. The diagnosis of external genital endometriosis can help comprehend patient complaints as well as conduct a survey, ultrasound examination, and sometimes magnetic resonance imaging. Several recent advances have been made to understand the mechanisms underlying endometriosis; however, invasive methods, such laparoscopy, are still the "gold standard" of diagnosis ${ }^{(5)}$. The search for possible biomarkers for the diagnosis of endometriosis continues. Among non-invasive methods, microrna is a candidate for further research ${ }^{(6)}$.

The microrna profile of blood and eutopic endometrium may provide important information in confirming diagnosis of endometriosis ${ }^{(7)}$.

Owing to their good sensitivity and specificity, molecular genetic methods might improve the results of infertility treatment associated with endometriosis through earlier treatment, including surgery ${ }^{(8)}$.

In addition, various research groups have high expectations regarding the role of microRNA in evaluating the effectiveness of drug therapy. In addition, microRNAs treatments have provided promising results for certain chronic diseases and cancers $^{(9)}$.

In our study, we selected microRNA let-7 and mir-9 as possible candidates. This is because of available data regarding the use of let-7 for treating diseases and use of mir-9 as microRNA, which induces apoptosis, thus playing a special role in the pathogenesis of endometriosis ${ }^{(10)}$.

The goal of this study was to determine the possible role of microRNA let-7 and mir-9 in the non-invasive diagnosis of endometriosis.

\section{Materials and Methods}

We explored the samples from 86 patients: 1) control group with relatively healthy individuals and 2) endometriosis group, which was further divided into subgroups according to Altman Self-Rating Mania scale (ASRM) I-II stages and III-IV stages. All patients had undergone laparoscopic surgical treatment at a medical center with confirmation of diagnosis via histology after complete clinical and laboratory examinations. Indication for laparoscopy was infertility and/or dyspareunia and dysmenorrhea. The prevalence of endometriosis was assessed by the same surgical team according to ASRM requirements (surgeon: MM). Laparoscopy was performed using standard 5-mm instruments including bipolar dissector and disposable scissors according to ESGE recommendations.

The control group (Figure 1) included 24 patients who had no signs of endometriosis before examining the pelvic organs and peritoneum by laparoscopic intervention. Group I included 29 patients with ASRM I-II stage "minimal" and "mild" endometriosis with lesions on peritoneum and ovary, but with total points of 4-15. In contrast, group II included 35 women with ASRM III-IV stage "moderate" and "severe" endometriosis, with total points from 16 to $>44^{(11)}$.

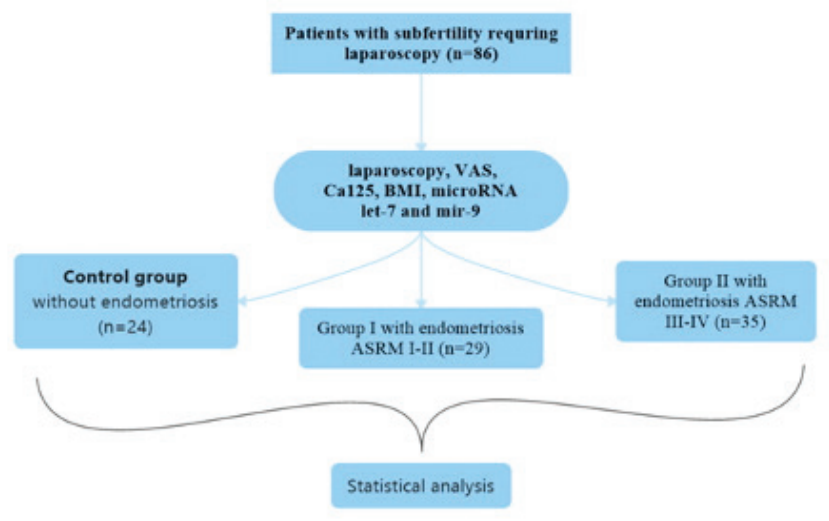

Figure 1. Study design

Except standard gynecological examination, vital sign assessment, body mass index (BMI), and serum cancer antigen-125 (CA-125) level determination were conducted for all patients at the Sinevo laboratory by enzyme-linked immunosorbent assay. Testing was performed using the Elecsys CA 125 II test system and Cobas 6000/Cobas 8000 analyzers from the Swiss company Roche Diagnostics. Method: Electrochemiluminescence immunoassay analyzer, in which the "antigen-antibody" reaction is initiated via an electric current, allows to control it with maximum selectivity and sensitivity. Principle of the method: First, patient sample is mixed with antibodies bound to biotin and antibodies bound to ruthenium, to form an "antigen-antibody" complex. After incubation of the mixture, paramagnetic microparticles with streptavidin (solid phase) are added. After the second incubation, the reaction mixture is transferred to the measuring cell of the apparatus, where under the action of the magnetic field, paramagnetic particles that are associated with the "antigen-antibody" complex are attracted to the electrode surface and non-antigen-bound antibodies are removed. Subsequently, an electric current is used to excite ruthenium and generate a signal that allows the detection of the "antigen-antibody" complex. The luminosity, measured photometrically, is equivalent to the concentration of the substance determined in the sample.

We evaluated the severity of pain syndrome in patients by visual analog scale (VAS) in millimeters (0: no pain; 100 
mm: worst possible pain). Patients' complaints were divided into three groups: infertility, pain syndrome, and absence of complaints. For all patients, ultrasound pelvic examination was performed using transvaginal transducer (7-12 MHz) and convex transducer $(3.5-8 \mathrm{MHz})^{(12)}$.

\section{MicroRNA Determination}

We used RNA-GO to obtain high-quality total RNA from cell samples (NanoDrop-1000). Next step involved reverse transcription for microRNA let-7 and mir-9 and control U6 (Tap Man microRNA Reverse Transcription Kit). The results obtained were analyzed using the software 7500 Fast realtime polymerase chain reaction (PCR) (Applied Biosystems, USA). All data are presented as arithmetic data (mean values \pm standard deviation).

\section{Statistical Analysis}

In total, 86 patients were included. Patient selection was based on the central limit theorem (CLT). A sample of 30 is the smallest sample size for which the CLT is still valid. The total sample size for the Manny-Whitney test at $\mathrm{P}(\mathrm{X}>\mathrm{Y})$

Table 1. Major demographic characteristics of patients

\begin{tabular}{|l|l|l|l|l|}
\hline & $\begin{array}{l}\text { ASRM } \\
\text { score }\end{array}$ & Age & BMI & $\begin{array}{l}\text { Level of } \\
\text { pain (VAS } \\
\text { score) }\end{array}$ \\
\hline Mean & 16.95 & 33.33 & 20.72 & 55.91 \\
\hline Std & 16.10 & 6.07 & 2.30 & 21.21 \\
\hline Minimum & 0 & 20 & 17 & 1 \\
\hline 25\% & 0.5 & 28 & 18.5 & 40 \\
\hline $50 \%$ & 13 & 33 & 19.85 & 60 \\
\hline 75\% & 34 & 38 & 22 & 70 \\
\hline Maximum & 45 & 45 & 30.1 & 95 \\
\hline $\begin{array}{l}\text { Std: Standard, BMI: Body mass index, VAS: Visual analog scale, } \\
\text { ASRM: Altman Self-Rating Mania scale }\end{array}$
\end{tabular}

Table 2. Main results of clinical laboratory and molecular genetic examinations of a prospective group of women with endometriosis

\begin{tabular}{|c|c|c|c|}
\hline & CA-125 & $\begin{array}{l}\text { Microrna } \\
\text { let-7 }\end{array}$ & $\begin{array}{l}\text { Microrna } \\
\text { mir-9 }\end{array}$ \\
\hline Count & 86 & 86 & 61 \\
\hline Mean & 56.42 & 33.72 & 5.00 \\
\hline Std & 30.93 & 81.69 & 25.82 \\
\hline Minimum & 3 & 0.03 & 0 \\
\hline $25 \%$ & 26.25 & 0.88 & 0.04 \\
\hline $50 \%$ & 62.5 & 4.43 & 0.11 \\
\hline $75 \%$ & 82 & 17.77 & 0.56 \\
\hline Maximum & 108 & 517.24 & 186.86 \\
\hline
\end{tabular}

STD: Standard
$=0.2065$, like in our case, should be at least 40 observations. The statistical power was 0.806 . For determining effect size, we used effect size Glass' $\Delta$ because standard deviations were significantly different between groups (12.22 vs 131.89). The effect size in our case was 0.822 . We determined the normality of distribution of the studied values using the Shapiro-Wilk method and obtained the following results: statistics $=0.455$, $\mathrm{p}=0.000$ (for alpha $=0.05$ ). Thus, it was possible to draw the conclusion about the "non normality" of data distribution in the sample by the main studied indicator (let- 7 microRNA). The main results of demographic characteristics presented in Table 1, i.e., clinical laboratory and molecular genetic examinations of a prospective group of women with endometriosis, are also presented in Table 2.

To determine the correlation ( $\mathrm{r}$ ), we used the Spearman method (used for non-normal distributed data). In addition, we used Mann-Whitney-Wilcoxon method with Bonferroni correction (used for non-normal distributed data) to determine the significance of the difference between the mean values of three groups: a control group and two endometriosis groups.

In our investigation, ANOVA was not conducted owing to the small number of groups and the ability to compare them in turn. Next, we performed ROC analysis to determine the possibility of using let-7 microRNA for non-invasive detection of endometriosis. Area under the curves for let 7 microRNA and CA-125 for endometriosis were also compared (Table 3, Figure 1).

Results of all groups were tested with respect to the normality of the statistical distribution. Statistical analysis was performed using SPSS Statistics 17.0 (IBM Corporation, USA) ${ }^{(13)}$.

This study was approved by the ethics committee (protocol number 3) and was conducted in accordance with the Helsinki declaration for clinical studies in humans. Informed consent for participation in the study was signed by all participants.

\section{Results}

The investigated groups had comparable average indicators of patient age. In contrast, BMI had lower values in the endometriosis groups (22.35 in control group; 20.16 and 20.15 in endometriosis groups I and II, respectively). Forty patients in the endometriosis group had an endometrioid cyst (62.5\%), with higher blood CA-125 levels, whereas the levels of let-7 did not depend significantly on the presence or absence of an endometriotic cyst. let-7 microRNA deviated considerably from the average value, and the scatter of values was considerably large (standard deviation: 81.69; average: 33.72 ). We evaluated the normality of data distribution in the sample using the Shapiro-Wilk test. This test was considered reliable for small samples containing up to 1000 values (we had 86). ShapiroWilk test result was as follows: statistics $=0.455, \mathrm{p}=0.000$ (for alpha $=0.05$ ). Thus, it was possible to conclude regarding the incorrect distribution of data in the sample by the main studied indicator (let-7 microRNA). 
There was a significant moderate negative correlation (-0.64) between let-7 microRNA and ASRM scores. In addition, the correlation between endometriosis (+/-) and let-7 microRNA was close to strong (-0.67), with a high degree of reliability and a negative character (Table 3 ).

The other indicator, mir-9, was found to be normally distributed (according to the Shapiro-Wilk test). mir-9 Was weakly correlated with ASRM scale. Mann-Whitney analysis showed that the difference in mir-9 mRNA between groups with and without endometriosis, as well as between groups with more clinically and histologically severe and mild endometriosis, was statistically insignificant. Thus, mir-9 mRNA was not an optimal candidate for diagnosing subclinical endometriosis (Figure 2). Both the indicators, microRNA let-7 and ASRM points, had reliable negative correlation (-0.64). In addition, the indicators of endometriosis (+/-) and microRNA let-7 correlated with the nearest strong value $(-0.67)$ owing to a high degree of reliability as well as a negative character (Table 3 ).

Mann-Whitney analysis revealed that microRNA let-7 was a reliable indicator between the group with and without endometriosis (Figure 3).

In addition, Mann-Whitney analysis demonstrated significant difference in let-7 microRNA between the groups of patients with and without endometriosis, as well as between groups with more clinically and histologically severe and mild endometriosis, making let-7 microRNA a clinically appealing biomarker than mir-9 mRNA.

According to the results of Prescott et al. ${ }^{(14)}$ the sensitivity and specificity of serum CA-125 for the diagnosis of endometriosis

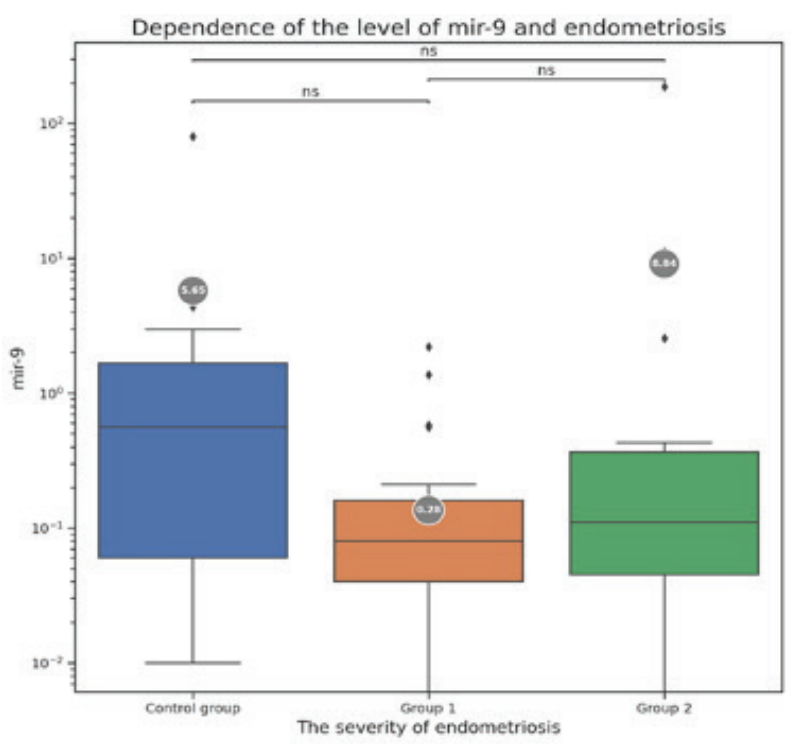

Figure 2. Level of mir-9 mRNA ( \pm standard deviation and statistically significant using Mann-Whitney-Wilcoxon test, twosided with Bonferroni correction) in groups of patients with mild endometriosis (group 1), more clinically and histologically severe endometriosis (group 2), and without endometriosis (control group)

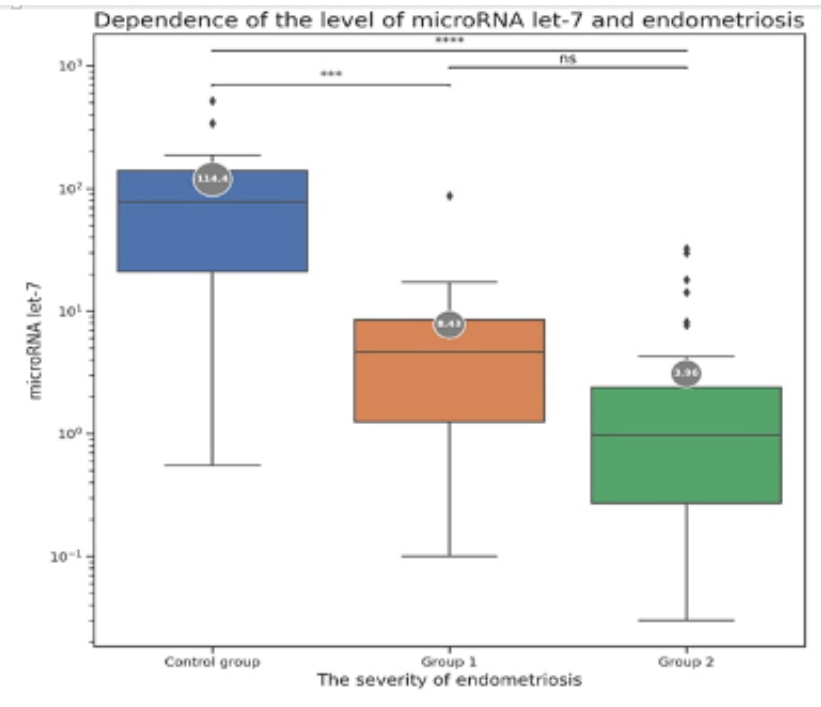

Figure 3. Level of microRNA let-7 ( \pm standard deviation and statistically significant using Mann-Whitney-Wilcoxon test, twosided with Bonferroni correction) in groups of patients with mild endometriosis (group 1), more clinically and histologically severe endometriosis (group 2), and without endometriosis (control group)

were $61.1 \%$ and $87.5 \%$. Elevated CA-125 (>35 U/mL) was noted in $65 / 75$ cases $(86.70 \%)$ with advanced endometriosis, but in only $15 / 56$ patients (26.8\%) with minimal and mild endometriosis, respectively. Santulli et al. ${ }^{(15)}$ demonstrated that serum CA-125 levels were significantly increased in women with severe forms of endometriosis, OMA, and DIE lesions. In addition, elevated serum CA-125 levels were associated with more severe and extended DIE lesions. CA-125 levels were not different from women without endometriosis' in women with superficial peritoneal lesions.

Based on promising data obtained from correlation analysis and group comparisons using Mann-Whitney test, we performed ROC analysis. The following indicators were determined in ROC analysis of microRNA let-7 and CA-125. For microRNA let-7, sensitivity was 92.563 , specificity was 82.545 , PPV was 93.912, and NPV was 79.234. Indicators of the classification model for CA-125 were as follows: sensitivity $=86.105$, specificity $=76.422, \mathrm{PPV}=91.397$, and NPV=65.406. The ROC analysis revealed that the flat under curve for microRNA let-7 was higher than that for CA-125 (Figure 4).

Thus, microRNA let-7 has the best parameters (sensitivity, specificity, and predictive value of positive and negative results). Comparison with CA-125 using ROC analysis showed the presence of a larger AUC. This indicates great prospects for this marker for early and sometimes preclinical diagnosis of endometriosis.

\section{Discussion}

CA-125 is a glycoprotein biomarker used in women with endometriosis, and according to some authors, this could 
Table 3. Spearman's rank correlation coefficient (r) for basic research indicators. Very weak: 0.00-1.99, weak: 0.20-399, medium: 0.40-0.599, strong: 0.60-0.799, very strong: 0.80-1.000. Significant level of correlation $(* * *: \mathrm{p}<0.01, * *: \mathrm{p}<0.05, *: \mathrm{p}<0.1)$

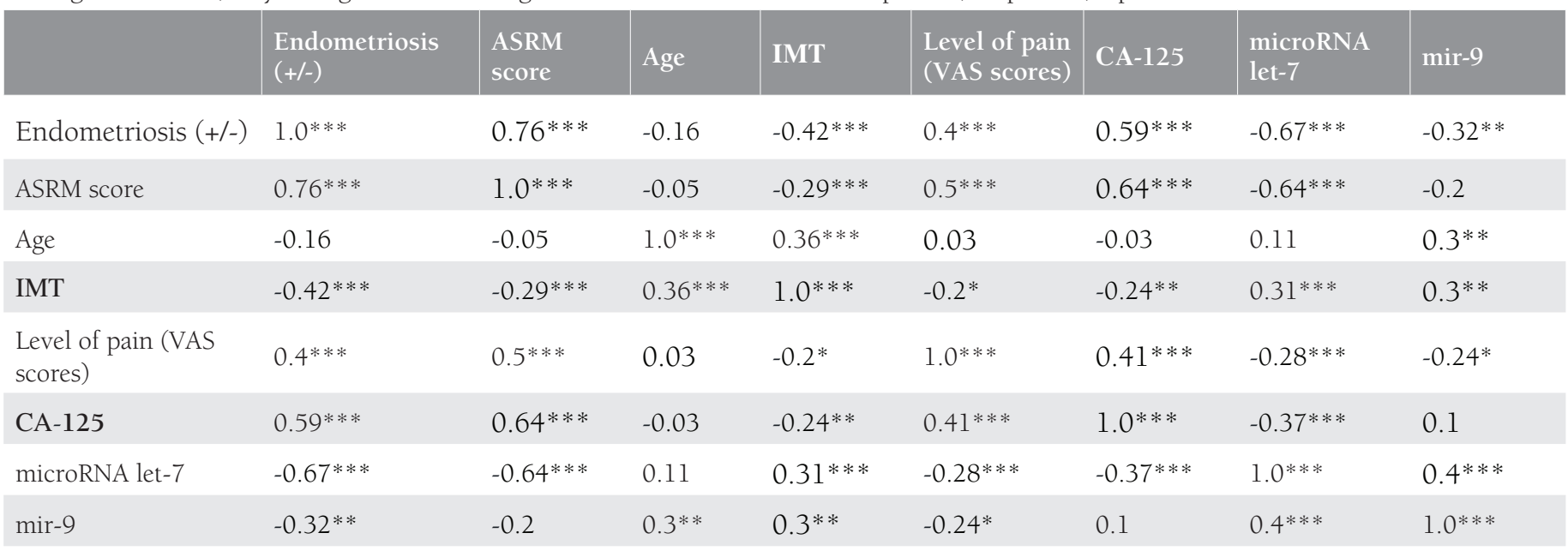

ASRM: Altman Self-Rating Mania scale, VAS: Visual analog scale

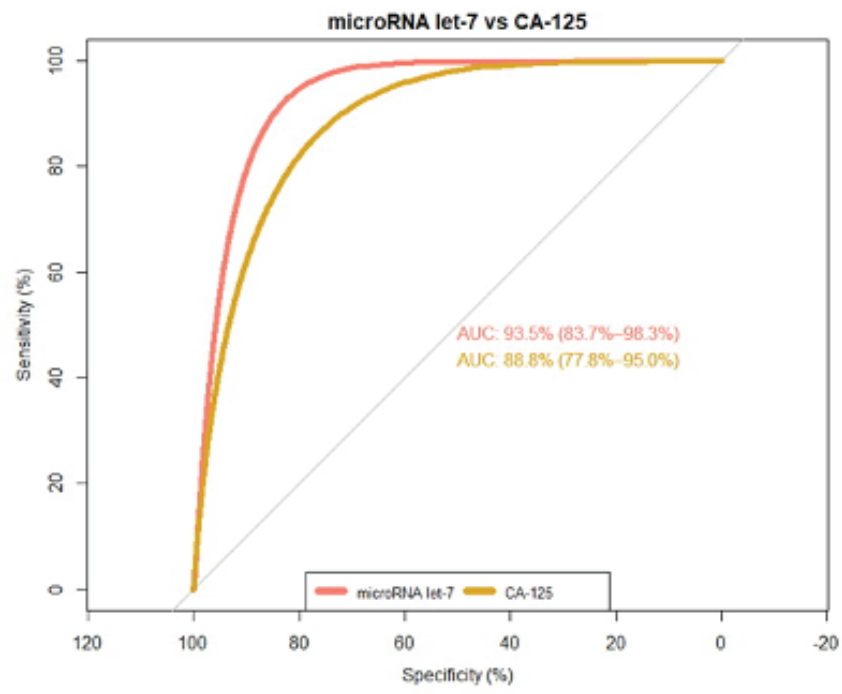

Figure 4. Sensitivity and specificity analyses for microRNA let-7 (AUC: $93.5 \%$ ) and for CA-125 (AUC: 88.8\%)

AUC: Area under the curve

be useful in practice among patients suspected to have endometriosis ${ }^{(16)}$. It has proven useful as an ovarian cancer biomarker for monitoring ovarian cancer therapy and early recurrences ${ }^{(17)}$. CA-125 levels have been found to be significantly higher in women with moderate or severe endometriosis, specifically for ovarian endometriomas and deeply infiltrating endometriosis ${ }^{(18)}$. A previous study analyzed serum CA-125 levels in 87 women aged 21-54 years suspected with endometriosis who had pelvic pain, dysmenorrhea, or dyspareunia. The mean age of the women was $32.22 \pm 6.91$ years. The mean serum CA-125 level was $49.93 \pm 4.30 \mathrm{U} / \mathrm{mL}$. There was a significant correlation between the endometriosis stage, lesion size, adhesion score, and preoperative CA-125 plasma concentration. The suggested preoperative serum cut- off levels in premenopausal and postmenopausal patients were 37 and $35 \mathrm{U} / \mathrm{mL}$, respectively ${ }^{(19)}$. The search for non-invasive biomarkers of endometriosis has been ongoing since a long time. In a related study, researchers investigated the serum levels of CA-125, TNF, IL-1, IL-6, and IL-8. The data obtained were correlated with clinical symptoms and revised American Fertility Society score and stage as well as interpreted using Mann-Whitney U-test and ANOVA regression analysis. CA125 levels were over the cut-off of 35 IU/L in 54\% of patients (versus $8 \%$ of controls), averaging 67.5 (95\% confidence interval: \pm 17.5 ). The sensitivity and specificity were $54 \%$ and $91 \%$, respectively, with a p-value of $<0.001$ (statistically significant). For IL-6, $71 \%$ of cases and $87 \%$ of controls were above the cut-off of $2 \mathrm{pg} / \mathrm{mL}$, with an average of $11.83 \pm 7$. The sensitivity and specificity were $71 \%$ and $12 \%$, respectively, but the difference was not statistically significant $(\mathrm{p}=0.071)$. Other tested serum markers had no discrimination value. ANOVA revealed a correlation between the severity of endometriosis and CA-125 ( $\mathrm{p}=0.03)$ but not for IL- $6^{(20)}$. These results have provided a reason for comparison of CA-125 as a non-invasive biomarker with certain specificity for endometriosis ${ }^{(21)}$.

The important disadvantage is that the level of CA-125 could increase in inflammatory processes and oncological diseases, so its specificity is rather low ${ }^{(22)}$. In contrast, the determination of microRNA let-7 level is more promising for all phenotypes and at stages of endometriosis ${ }^{(23)}$. Chronic inflammation caused by the presence of fragments of ectopic endometrium and activation of myofibroblasts with the development of fibrous tissue leads to potential modifications of epigenetic programming, i.e., aberrant regulation of gene transcription and posttranslational regulatory mechanisms through noncoding RNA ${ }^{(24)}$. Previously, researchers have described ways to regulate H19/Let-7/IGF1R as well as the mechanisms that 
contributes to endometrial dysfunction and is leading in the development of endometriosis and associated infertility. However, the method of determining H19 is very complex. H19 is quite unstable, and the determination of let- 7 can be performed using real-time PCR and appropriate reagents for the isolation of miRNAs from biological substances ${ }^{(25)}$. Changes in epigenetics contribute to the development of resistance to progesterone and increased response to estrogen, which are the two key characteristics of women with endometriosis. Severity of fibrosis, i.e., the stage and spread of the disease, can potentially indicate the effectiveness of drug treatment ${ }^{(26)}$. The use of let-7 as a biomarker will help predict the response to drug therapy and choose the best treatment ${ }^{(27)}$.

\section{Conclusion}

We believe that the measurement of microRNA let-7 is promising for routine use in patients with endometriosis. Considering data on microRNA let-7 as well as clinical data, we are planning an algorithm for diagnosis and management that will help identify the extent of endometriosis without laparoscopy at an earlier stage and help select an effective therapy for lower period of time. This approach could possibly decrease time to diagnosis, decrease surgery rate, and optimize overall endometriosis treatment results, including VAS score and fertility results.

\section{Ethics}

Ethics Committee Approval: This study was approved by the ethics committee (protocol number: 3 ) and was conducted in accordance with the Helsinki Declaration for clinical studies in humans.

Informed Consent: Informed consent for participation in the study was signed by all participants.

Peer-review: Externally peer-reviewed.

\section{Authorship Contributions}

Concept: D.A.P., M.V.M., Design: D.A.P., M.V.M., Data Collection or Processing: D.A.P., M.V.M., Analysis or Interpretation: V.V., Literature Search: D.A.P., M.V.M., Writing: D.A.P., M.V.M., V.V.

Conflict of Interest: No conflict of interest was declared by the authors.

Financial Disclosure: The authors declared that this study received no financial support.

\section{References}

1. Ballard K, Lowton K, Wright J. What's the delay? A qualitative study of women's experiences of reaching a diagnosis of endometriosis. Fertil Steril 2006;86:1296-301.

2. Aurélie C, Pauline C, Michel C, Grémeau A-S, Pouly J-L, Rabischong B, et al. Patient Quality of Life and Symptoms after Surgical Treatment for Endometriosis. J Minim Invasive Gynecol 2019;26:717-26.

3. Parasar P, Ozcan P, Terry KL. Endometriosis: Epidemiology, Diagnosis and Clinical Management Curr Obstet Gynecol Rep 2017;6:34-41.
4. Missmer S, Hankinson S, Spiegelman D, Barbieri R, Marshall L, Hunter D. Incidence of laparoscopically confirmed endometriosis by demographic, anthropometric and lifestyle factors. Am J Epidemiol 2004;160:784-96.

5. Dunselman G, Vermeule N, Becker C, Calhaz-Jorge C, D 'Hooghe $\mathrm{T}$, De Bie B, et al. Management of women with endometriosis. Guideline ESHRE. Hum Reprod 2014;29:400-12.

6. Matthew D, Parvez I, Dyan N, Konje J. The emerging role of epigenetics and miRNAs in endometriosis. J Obstet Gynecol 2011;6:431-50

7. Borghese B, Zondervan K, Abrao M, Chapron M, Vaiman D. Recent insights on the genetics and epigenetics of endometriosis. Clin Genet 2017;91:254-64.

8. Koninckx PR, Ussia A, Adamyan L, Wattiez A, Gomel V, Martin DC, et al. Pathogenesis of endometriosis: the genetic/epigenetic theory Fertility and Sterility 2019;111:327-40.

9. Ohlsson Teague M, Van der Hoek KH, Van der Hoek M, Perry N, Wagaarachchi P, Robertson SA, et al. MicroRNA-regulated pathways associated with endometriosis Mol Endocrinol 2009;23:265-75.

10. Cagdas S, Ramanaiah M, Kyong W. Yi, Hugh S. MicroRNA Let-7b: A Novel treatment for endometriosis J Cell Mol Med 2018;22:534653.

11. American Society for Reproductive Medicine classification of endometriosis. Fertil Steril 1997;67:817-21.

12. Vercellini P, Fedele L, Aimi G, Pietropaolo G, Consonni D, Crosignani PG. Association between endometriosis stage, lesion type, patient characteristics and severity of pelvic pain symptoms: a multivariate analysis of over 1000 patients. Hum Reprod 2007;22:266-71.

13. Whittier N, Wildhagen T, Gold H. Statistics for social understanding with stata and SPSS. Washington: Rowman \& Littlefield Publishers; 2019:210-45.

14. Prescott J, Farland L, Tobias D, Gaskins A, Gaskins AJ, Spiegelman $\mathrm{D}$, et al. A prospective cohort study of endometriosis and subsequent risk of infertility. Hum Reprod 2016;31:1475-82.

15. Santulli P, Streuli I, Melonio I, Marcellin L, M'Baye M, Bititi A, et al. Increased Serum Cancer Antigen-125 Is a Marker for Severity of Deep Endometriosis. J Minim Invasive Gynecol 2015;22: 275-84.

16. Pittaway D, Rondinone D, Miller K, Barnes K. Clinical evaluation of CA-125 concentrations as a prognostic factor for pregnancy in infertile women with surgically treated endometriosis. Fertil Steril 1995;64:321-4.

17. Jiang T, Huang L, Zhang S. Preoperative serum CA125: a useful marker for surgical management of endometrial cancer. BMC Cancer 2015;12:390-6.

18. Szubert M, Suzin J, Wierzbowski T, Kowalczyk-Amico K. CA125 concentration in serum and peritoneal fluid in patients with endometriosis - preliminary results. Arch Med Sci 2012;8:504-8.

19. Karimi-Zarchi M, Dehshiri-Zadeh N, Sekhavat L, Nosouhi F. Correlation of CA-125 serum level and clinico-pathological characteristic of patients with endometriosis. Int J Reprod Biomed 2016;14:713-8.

20. Socolov R, Butureanu S, Angioni S, Sindilar A, Boiculese L, Cozma $\mathrm{L}$, et al. The value of serological markers in the diagnosis and prognosis of endometriosis: a prospective case-control study. Eur J Obstet Gynecol Reprod Biol 2011;154:215-217.

21. Japur de Sá Rosa-e-Silva A C, Rosa e Silva J C, Ferriani A R. Serum CA-125 in the diagnosis of endometriosis. Int J Gynaecol Obstet 2007;96:206-7.

22. Kobayashi H, Kajihara H, Yamada Y, Tanase Y, Kanayama S, Furukawa N, et al. Risk of carcinoma in women with ovarian endometrioma. Front Biosci 2011;3:529-39. 
23. Cosar E, Mamillapalli R, Ersoy GS, Cho SY, Seifer B, Taylor H S. Serum microRNAs as diagnostic markers of endometriosis: a comprehensive array based analysis. Fertil Steril 2016;106:402-9.

24. Bjorkman S, Taylor HS. MicroRNAs in endometriosis: biological function and emerging biomarker candidates. Biol Reprod 2019;100:1135-46

25. Ghazal S, McKinnon B, Zhou J, Mueller M, Men Y, Yang L, et al. H19 lncRNA alters stromal cell growth via IGF signaling in the endometrium of women with endometriosis. EMBO Mol Med 2015;7:996-1003.

26. Grechukhina O, Petracco R, Popkhadze S, Massasa E, Paranjape T, Chan E, et al. A polymorphism in a let-7 microRNA binding site of KRAS in women with endometriosis. EMBO Mol Med 2012;4:20617.

27. Al-Sabbagh M, Lam EW, Brosens JJ. Mechanisms of endometrial progesterone resistance. Mol Cell Endocrinol 2012;358:208-15. 